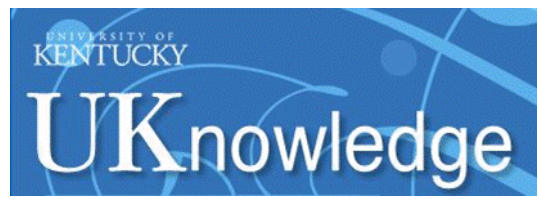

University of Kentucky

UKnowledge

Biosystems and Agricultural Engineering Faculty Publications

7-5-2016

\title{
Physicochemical and Functional Properties of Extruded Sorghum-Based Bean Analog
}

\author{
Akinbode A. Adedeji \\ University of Kentucky, akinbode.adedeji@uky.edu \\ Michael V. Joseph \\ Kansas State University \\ Brian Platter \\ Wenger Manufacturing \\ Sajid Alavi \\ Kansas State University
}

Follow this and additional works at: https://uknowledge.uky.edu/bae_facpub

Part of the Bioresource and Agricultural Engineering Commons, and the Food Processing Commons Right click to open a feedback form in a new tab to let us know how this document benefits you.

\section{Repository Citation}

Adedeji, Akinbode A.; Joseph, Michael V.; Platter, Brian; and Alavi, Sajid, "Physicochemical and Functional Properties of Extruded Sorghum-Based Bean Analog" (2016). Biosystems and Agricultural Engineering Faculty Publications. 23.

https://uknowledge.uky.edu/bae_facpub/23

This Article is brought to you for free and open access by the Biosystems and Agricultural Engineering at UKnowledge. It has been accepted for inclusion in Biosystems and Agricultural Engineering Faculty Publications by an authorized administrator of UKnowledge. For more information, please contact UKnowledge@lsv.uky.edu. 


\section{Physicochemical and Functional Properties of Extruded Sorghum-Based Bean Analog}

Digital Object Identifier (DOI)

https://doi.org/10.1111/jfpe.12401

Notes/Citation Information

Published in Journal of Food Process Engineering, v. 40, issue 2, e12401, p. 1-14.

(C) 2016 Wiley Periodicals, Inc

The copyright holder has granted the permission for posting the article here.

This is the peer reviewed version of the following article: Adedeji, A. A., Joesph, M. V., Plattner, B., \& Alavi, S. (2016). Physicochemical and functional properties of extruded sorghum-based bean analog. Journal of Food Process Engineering, 40(2), 1-14. https://doi.org/10.1111/jfpe.12401, which has been published in final form at https://doi.org/10.1111/jfpe.12401. This article may be used for non-commercial purposes in accordance with Wiley Terms and Conditions for Self-Archiving. 


\title{
PHYSICOCHEMICAL AND FUNCTIONAL PROPERTIES OF EXTRUDED SORGHUM-BASED BEAN ANALOG
}

\author{
AKINBODE A. ADEDEJI ${ }^{1,2}$, MICHAEL V. JOSEPH ${ }^{1}$, BRIAN PLATTNER ${ }^{3}$ and SAJID ALAVI ${ }^{1,4}$ \\ ${ }^{1}$ Department of Grain Science and Industry, Kansas State University, Manhattan, KS \\ ${ }^{2}$ Biosystems and Agricultural Engineering Department, University of Kentucky, Lexington, KY \\ ${ }^{3}$ Wenger Manufacturing, Sabetha, KS
}

${ }^{4}$ Corresponding author.

TEL: + 785-532-2403;

FAX: 785-532-4017;

EMAIL: salavi@ksu.edu

Received for Publication February 12, 2016

Accepted for Publication April 5, 2016

doi:10.1111/jfpe.12401

\begin{abstract}
The objective of this study was to develop and evaluate the physicochemical and functional properties of a bean like product made from cold extrusion of sorghum, soy and wheat flours. Formulated samples comprised of sorghum (25-70\%), wheat $(0-35 \%)$ and soy $(30-50 \%)$ flours. The degree of gelatinization ranged from 54.1 to $93.6 \%$. Pasting curves showed minimal starch damage with peak and final viscosities in the range of 456.0-1138.5 and 297-584 cP, respectively. Textural properties of the extrudates were significantly impacted by starch content and cooking time. There was significant cooking loss due to poor binding properties of the extrudates. Cooking the product for $30 \mathrm{~min}$ after $2 \mathrm{~h}$ soaking gave comparable hardness to cooked navy bean. Texture profile analysis showed that mostly starchbased ingredients contributed to hardness and cohesiveness, while formulations high in protein showed increased adhesiveness and gumminess.
\end{abstract}

\section{PRACTICAL APPLICATIONS}

This study addressed a major gap in access to sufficient nutrient in navy beans, a common staple, the processability subject, and offers a novel approach to addressing them. Beans are common staple in many regions where malnutrition is prevalent, and some types of beans take long to cook to a texture acceptable due to changes during storage. Reforming beans using extrusion allows manipulation of ingredients that can help to address deficiencies in nutrient, flatulence and the "hard to cook" characteristics seen in some beans. Bean analog, as we refer to extruded bean in this study, is a major mechanism for nutrient delivery which has the potential to help address macronutrient and micronutrient deficiencies in diets of people where beans is a staple.

\section{INTRODUCTION}

Beans (Phaseolus vulgaris) come in various forms, shape, size and color. The various variety of beans are known by different names such as black eye pea, black turtle bean, pinto bean, lima bean, navy bean, cowpea, etc. They are common staple in many parts of the world and also a major source of protein for many families especially in the developing regions such as sub-Saharan Africa, South and Central America and Asia, where animal source of protein is scarce, unaffordable, or because of cultural and religion reasons. It is also common among Asians in North America. Beans contain between 18 and $40 \%$ protein and 38 and $60 \%$ carbohydrates (Queiroz et al. 2002). They are also reported to be a good source of vitamins, dietary fiber, minerals (calcium, iron, zinc, phosphorus, potassium and magnesium), phytochemicals and unsaturated fatty acids (Boateng et al. 2008; Tosh and Yada 2010). Major challenges to consumption of beans are the "hard to cook" (HTC) characteristics, poor protein digestibility, deficiency in some essential amino acids namely the sulfur-containing amino acids (methionine, tryptophan and cysteine), the presence of oligosaccharides such as raffinose and stachyose that cause flatulence if not 
properly processed, and the presence of anti-nutritional factors such as phytic acid, trypsin inhibitors and tannins that bind important nutrients, thus decreasing their bioaccessibility (Baudoin and Maquet 1999; Yasmin et al. 2008; Khattab and Arntfield 2009).

The concept of producing food analog, a product that mimics the natural one is a recent trend that has provided avenue to bolster nutritional property, increase homogeneity of constituent, improve preparatory method, reduce production cost, and produce foods with greater appeal. Examples include extruded rice, which exists in various forms and made from different ingredients such as wheat, soy and rice flours with added micronutrients like vitamin A which is insufficient in the natural rice (Gonzalez et al. 2002; Alavi et al. 2008; Yoo et al. 2013; Adedeji et al. 2016). Another such imitation product is Lentil analog, which has found wide acceptance among the people of India sub-continent because of its quality attributes and similarity to natural lentil (Kodavali et al. 2012; Abu-Ghoush et al. 2015).

Grain sorghum is the fifth most produced grain in the world and the fourth in USA. Africa (Nigeria and Sudan), Americas (USA and Mexico) and Asia (India) are the largest producers of sorghum (USDA 2010). In the United States, sorghum is grown mainly for animal feed and recently as a renewable resource for energy production, e.g., ethanol production. However, in emerging regions such as Africa and Asia, it is a major staple prepared into various dishes, alcoholic and nonalcoholic beverages. Poor protein and starch digestibility, and presence of anti-nutritional factors such as phytic acid and tannins are partly responsible for concerns about its usage in human food (Alonso et al. 2000). However, some of these concerns can be addressed by processing. Extrusion processing has been reported to improve digestibility of sorghum protein and lead to reduction in anti-nutritional factors (Fapojuwo et al. 1987; de MesaStonestreet et al. 2012). Addressing the issue of antinutritional factors in sorghum would give it an excellent nutrient profile, being a good source of starch, protein and fiber. The use of sorghum as the main ingredient for the production of a product that mimics beans will allow target change in macronutrients, and potential use as mechanism for carrying micronutrient to address the issue of "hidden hunger." This will be a major step toward value-addition to this under-utilized grain (Rooney 2003; de Mesa Stonestreet et al. 2010).

The US government supports various food assistance programs yearly under its Public Law 480 and Title II Program, which are tagged "Food for Peace" and food for combating malnutrition, respectively. In 2011, US provided 1.8 million metric tons of food assistances to about 53 million foodinsecure people in 82 countries in several regions of the world that worth hundreds of millions of dollars (USAID 2011). Various products such as corn-soy blend and peanut
TABLE 1. BEAN ANALOG FLOUR BLEND

\begin{tabular}{llll}
\hline Formulation & Sorghum & Wheat & Soy \\
\hline S35W35Y30 & 35.0 & 35.0 & 30.0 \\
S52W17Y30 & 52.5 & 17.5 & 30.0 \\
S70W0Y30 & 70.0 & 0.00 & 30.0 \\
S25W25Y50 & 25.0 & 25.0 & 50.0 \\
S37W12Y50 & 37.5 & 12.5 & 50.0 \\
S50W0Y50 & 50.0 & 0.00 & 50.0
\end{tabular}

S\#W\#Y\# depicts the level of sorghum, wheat and soy flours in the formulation in percentage.

paste are commonly served. The present effort is geared towards increased food aid provision at reduced cost and a more effective outcome in terms of wide acceptability of the product because of the familiarity of people to be fed with the base ingredient - sorghum, and the potential to use the product as a mechanism for nutrient delivery (Joseph et al. 2013). Bean analog also has a potential use commercially; it could become a product used by all because of its unique quality and appeal. Therefore, the objective of this study was to develop a navy bean like product from sorghum, soy and wheat flours using cold extrusion process, and characterize to its physicochemical and functional properties.

\section{MATERIALS AND METHODS}

\section{Materials}

The decorticated white sorghum flour used was obtained from ADM Milling Company (Overland Park, KS). Defatted soy flour was purchased from Batory Foods, Kansas city, MO. Wheat flour was from Cereal Food Processor, Kansas city, KS. Salt was purchased from Kansas State University Food Store, while monoglycerides was donated by Danisco New Century, KS. Titanium oxide was purchased from Sensient Technologies, Missouri.

\section{Extrusion Process}

Bean analog was produced from a combination of sorghum $(25-70 \%)$, wheat $(0-35 \%)$ and soy $(30-50 \%)$ flours, processed in a twin screw extruder (TX-52, Wenger Manufacturing, Sabetha, KS) to make partially cooked, dense, high protein pellets, similar in shape (ellipsoidal) and size to navy beans. Sorghum and wheat flours were mixed at three ratios namely 100:0, 75:25 and 50:50. And then the mixed sorghum and wheat flour were blended with soy flour at two ratios of 50:50 and 70:30 (Table 1). In each treatment, 98\% of the flour blend, $1 \%$ each of salt (for taste) and monoglycerides (to reduce stickiness) were further blended together. Titanium oxide, a coloring agent (whitener) was added at $0.25 \%$ mass of all other ingredients. The extruder screw 


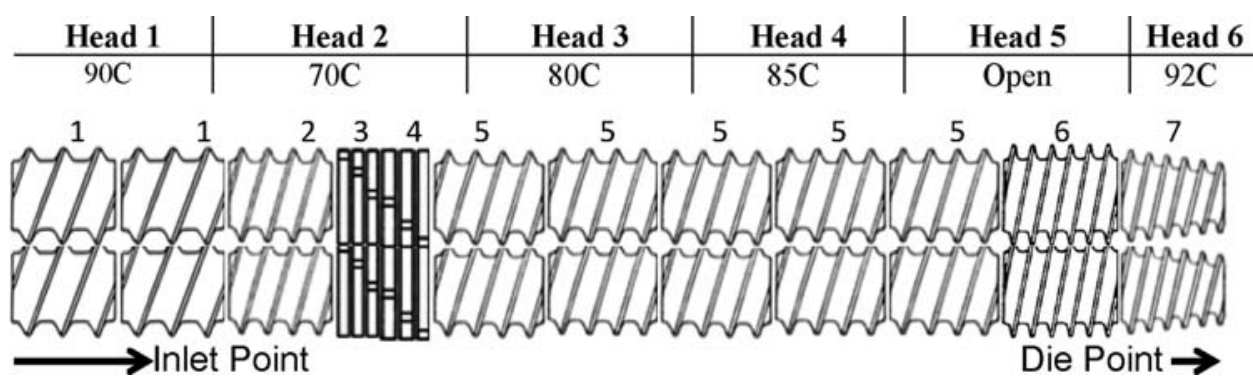

FIG. 1. EXTRUDER SCREW ELEMENTS CONFIGURATION SCHEMATICS AND BARREL TEMPERATURES. SCREW ELEMENTS (SE) 1-2 (FULL PITCH, DOUBLE FLIGHTED, UNCUT AND FORWARD); SE 3-4 (FORWARD AND REVERSE KNEADING BLOCKS, RESPECTIVELY); SE 5 (3/4 PITCH, DOUBLE FLIGHTED, UNCUT AND FORWARD); SE 6 (1/2 PITCH, DOUBLE FLIGHTED, UNCUT AND FORWARD); AND SE 7 (3/4 PITCH, DOUBLE FLIGHTED, UNCUT, CONE AND FORWARD)

configuration is shown in Fig. 1, and it was operated at a feed rate of $75 \mathrm{~kg} / \mathrm{h}$. The screw speed used was $150 \pm 10 \mathrm{rpm}$, which was based on trials set to maintain the throughput rate at $75 \mathrm{~kg} / \mathrm{h}$ and for minimum shear on the melt in the extruder. Extruded samples were dried in a Wenger Series 4800 Dryer (Wenger Manufacturing, Sabetha, KS) at $176^{\circ} \mathrm{F}$ $\left(80^{\circ} \mathrm{C}\right)$ in three cycles of $70 \mathrm{~min}$ each with $50 \%$ steam injection to prevent cracking, and a target final moisture content of approximately $11 \%$ wet weight basis (wb).

\section{Proximate Analysis}

Starch, crude protein, crude fat, crude fiber and ash content of the three (sorghum, wheat and defatted soy) flours were determined using the AOAC methods (AOAC 2010; AOCS 2009). These include determination of moisture according to AOAC method 930.15 which involve heating in air oven at $135^{\circ} \mathrm{C}$ for $2 \mathrm{~h}$; crude protein was based on nitrogen by combustion, 6.25X; AOAC 990.03; crude fat was obtained by petroleum ether extraction method, AOAC 920.39; ash was determined by heating at $600^{\circ} \mathrm{C}$ for $2 \mathrm{~h}$ according to AOAC 942.05; crude fiber content was obtained by filter bag technique utilizing $\mathrm{H}_{2} \mathrm{SO}_{4}$ and $\mathrm{NaOH}$ digestion according to AOCS $\mathrm{Ba} 6 \mathrm{a}-05$; and total starch was determined by aqueous alcohol pretreatment, then followed by amyloglucosidase $/ \alpha$-amylase treatment according to AOAC 996.11. All were determined on wet weight basis. Carbohydrate content was determined by subtracting the sum of other proximate content, except starch from 100. All samples were reported as mean of at least 2 replicates. The proximate content of each formulation was estimated from the mass fraction of each ingredient present in the formulation.

\section{Specific Mechanical Energy (SME)}

Specific mechanical energy was calculated using the following equation:

$$
S M E(k J / k g)=\frac{\left(\frac{\tau-\tau_{0}}{100}\right) \times \frac{N}{N_{r}} \times P_{r}}{\dot{m}},
$$

where $\tau$ is the \% torque during extrusion; $\tau_{0}$ is the no load $\%$ torque; $N$ is the extruder screw speed (rpm); $N_{r}$ is the rated screw speed $(336 \mathrm{rpm}) ; P_{r}$ is the rated motor power (23.3 $\mathrm{kW})$; and $\dot{m}$ is the mass flow rate or throughput $(\mathrm{kg} / \mathrm{s})$.

\section{Bulk Density and Moisture Content Determination}

Bulk density of the bean analog, before and after drying was determined from the mass of $1 \mathrm{~L}$ full cup of each extrudate. Bulk density was computed as mass per unit volume. Inbarrel moisture content was determined wet weight basis using a simple mass balance procedure that account for both inherent and injected moisture into the samples. Moisture content for the extrudate before and after drying was determined by standard method recommended by AACC method 44.19 (AOAC 930.15) (AOAC 2010) for grains. Approximately $2 \mathrm{~g} \pm 1 \mathrm{mg}$ of ground samples was measured into a $50 \mathrm{~mm}$ diameter pan and heated for $2 \mathrm{~h}$ at $135^{\circ} \mathrm{C}$. The pans were then covered and allowed to equilibrate in a desiccator for $30 \mathrm{~min}$ before weighing. The difference in mass before and after drying divided by the initial weight was used to compute moisture content on wet weight basis (wb):

Moisture content $(\mathrm{wb})=\frac{\text { Initial mass }- \text { final mass }}{\text { Initial mass }} \times 100 \%$.

\section{Color Measurement}

Color measurements were made using a Minolta Chromameter CR-210 (Ramsey, NJ). The equipment was calibrated prior to use with a white standard plate. Color data for navy bean and bean analog were measured by exposure to light reflectance translated into the CIE color space namely $L^{*}, a^{*}$ 
and $b^{\star}$. The three color spaces were obtained for each sample where $L^{*}$ represents brightness with 0 indicating whiteness and 100 complete black, $+a^{*}$ represents redness, $-a^{*}$ represents greenness, $+b^{\star}$ represents yellowness and $-b^{\star}$ represents blueness. The overall color difference, $\Delta E$ between navy and bean analog samples was calculated using the following equation:

$$
\Delta E=\sqrt{\left(L_{s}^{*}-L_{n b}^{*}\right)^{2}+\left(a_{s}^{*}-a_{n b}^{*}\right)^{2}+\left(b_{s}^{*}-b_{n b}^{*}\right)^{2}},
$$

where $s$ is the bean analog samples and $n b$ is navy bean.

\section{Pasting Property}

The extruded bean analog samples were further dried in a cabinet oven (Thelco Laboratory Oven, Precision Scientific, West Cortland, IL) at $55^{\circ} \mathrm{C}$ to attain a moisture content of about 7\% for ease of grinding in roller mills (915/9X6, Ross Machine and Mill Supply, Inc., Oklahoma City, OK). The samples were ground in two cycles through breaking rolls with approximate gap of $0.686 \mathrm{~mm}$, and through fine rolls with a gap of $0.076 \mathrm{~mm}$ in another two cycles. Approximately $95 \%$ passed through a $240 \mu \mathrm{m}$ sieve to meet the recommended particle size $(<250 \mu \mathrm{m})$ for RVA analysis (Crosbie and Ross 2007). The pasting properties of the ground samples were determined using a Rapid Visco Analyzer, RVA (RVA4, Newport Scientific Pvt. Ltd., Australia). Water was added to dry ground bean analog to hydrate to $14 \%$ moisture content to $3.5 \mathrm{~g}$ of hydrated sample $25 \mathrm{~mL}$ of distilled water was added and a procedure involving the standard RVA time-temperature profile was followed. The RVA was preheated at $50^{\circ} \mathrm{C}$ for $30 \mathrm{~min}$ prior to testing. After an initial vigorous stirring at $960 \mathrm{rpm}$ for $10 \mathrm{~s}$, the speed was reduced to $160 \mathrm{rpm}$. There was a minute holding time at $50^{\circ} \mathrm{C}$, and temperature was ramped to $95^{\circ} \mathrm{C}$ was $3 \mathrm{~min} 42 \mathrm{~s}$. Temperature was then held at $95^{\circ} \mathrm{C}$ for $2 \min 30$ before cooling to $50^{\circ} \mathrm{C}$ for $3 \mathrm{~min} 48 \mathrm{~s}$, and then held for 2 min at $50^{\circ} \mathrm{C}$. Pasting properties such as peak, breakdown, trough and final viscosities, were obtained from the output graph.

\section{Degree of Gelatinization}

Bean analog samples were ground in a similar way to the method for pasting property. The ground samples were mixed with water at a ratio of 1:2, i.e., dry matter to moisture (adjusting for moisture present in the sample). After thorough mixing in a beaker with glass paddle, it was allowed to stand at refrigeration temperature overnight (12 h) for equilibration. Approximately, $10 \mathrm{mg}$ of hydrated sample was scooped into a stainless steel high volume pan and closed with a lid with O-ring insertion. The closed pan was placed a differential scanning calorimeter (Q200, TA
Instrument, Delaware) sample cell with an empty closed pan, which served as the reference. The cell was closed and the pans were heated at a rate of $10^{\circ} \mathrm{C} / \mathrm{min}$ from 10 to $130^{\circ} \mathrm{C}$. The process was also repeated for the raw flour blends used for extrusion. Integration of the endothermic peaks of thermograms for both the raw flour and extruded bean analog samples was carried out on a TA Data Analyses software (version 4.7.2, Perkin-Elmer Corp., Norwalk, CT). The degree of gelatinization (DG) was calculated by comparing the endothermic heat obtained for bean analog $\left(\Delta H_{\text {bean }}\right.$ analog) to the endothermic heat, for the raw flour blends used for extrusion ( $\Delta H_{\text {raw flour }}$ ), using the following expression:

Degree of gelatinization $=\left(\frac{\Delta H_{\text {raw flour }}-\Delta H_{\text {bean analog }}}{\Delta H_{\text {raw flour }}}\right) \times 100 \%$.

\section{Radial Expansion}

Expansion ratio (ER) of bean analog samples was determined as the cross-section of the extrudate relative to that of the die orifice, based on eq. (5):

$$
E R=\frac{d^{2}}{d_{\mathrm{die}}^{2}},
$$

where $d$ is the extrudate diameter and $d_{\text {die }}$ is the diameter of the die, which was averaged from five measurements using digital caliper.

\section{Texture Profile Analysis (TPA)}

Bean analog samples were cooked based on the outcome of a preliminary study on navy beans. Approximately $20 \mathrm{~g}$ of bean analog was weighed and placed in a $600 \mathrm{~mL}$ beaker. Two-hundred milliliter of distilled water was added to the sample and was allowed to stand undisturbed for different time intervals namely $0,1 / 2,1,2,3$ and $4 \mathrm{~h}$, to represent different soaking times. At the end of each soaking time water was drained and the soaked bean analogs were cooked.

For the cooking, $300 \mathrm{~mL}$ of distilled water was brought to boil in a steel vessel placed on top of gas stove/burner. The bean and cooking water ratio was kept at 1:5 to allow sufficient water for cooking. Soaked bean analog was added to the boiling water to start the cooking process. The flame/heat was reduced to simmer level when the bean analog and water started boiling. Additional boiled water was added to the cooking vessel to maintain the level of water at least $2.54 \mathrm{~cm}$ above the beans. The bean analogs were cooked for three different durations namely 20, 25 and $30 \mathrm{~min}$, in order to determine the optimum cooking time. The cooking water was discarded after cooking was over. Twenty gram of navy bean was added to $300 \mathrm{~mL}$ distilled water already boiling, and it 
FIG. 2. NAVY BEANS AND
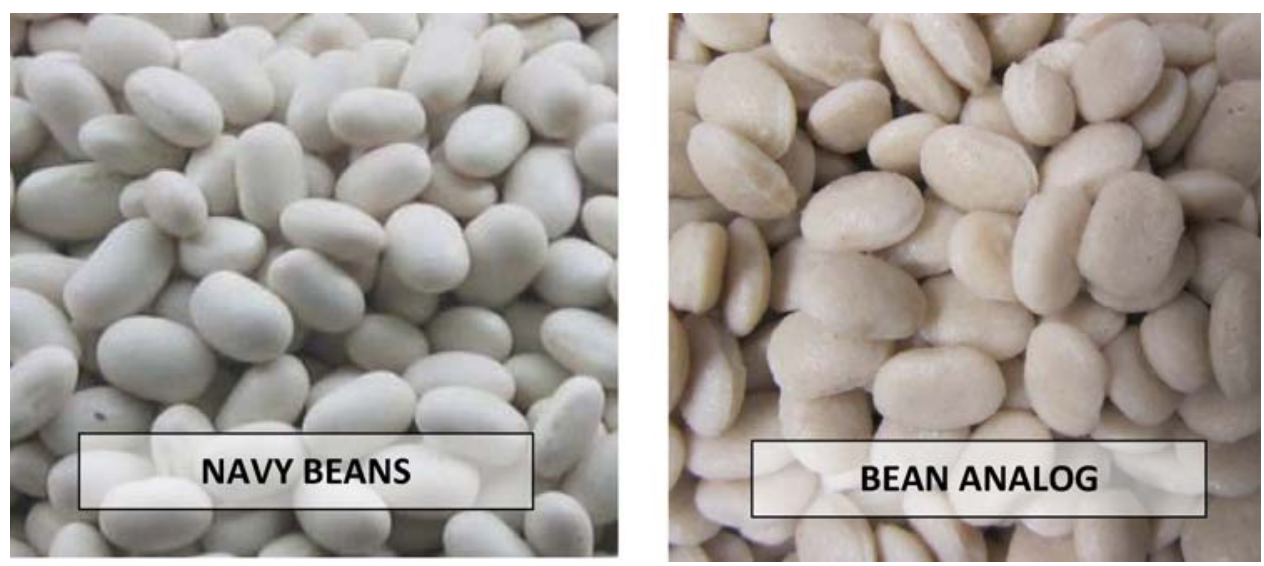
BEAN ANALOG

was cooked for $90 \mathrm{~min}$. The cooking was complete after 90 min of cooking. The cooking water was discarded at the end.

The cooked bean analog and navy beans were subjected to texture profile analysis (TPA) to assess the best soaking and cooking time combination that would closely imitate the textural properties of cooked navy beans. A texture analyzer (TA-XT2, Texture Technologies, Scarsdale, NY) with a $30 \mathrm{~kg}$ load cell was used for the TPA test. A cylindrical probe with $35 \mathrm{~mm}$ diameter was set to travel at $3 \mathrm{~mm} / \mathrm{s}$ from a height of $15 \mathrm{~mm}$ above the base/platform. The probe was programmed to travel to produce $75 \%$ strain. A grain of cooked bean ana$\log$ was placed on the platform below the probe for each texture analysis. A two cycle compression was performed, the resultant force $(\mathrm{g})$ versus time $(\mathrm{s})$ curves were used to derive TPA attributes of hardness (peak height of first compression), adhesiveness (negative work on the first upstroke), cohesiveness (ratio of area under second compression to the area under first compression), springiness (ratio of distance travelled by probe on the two curves), gumminess (cohesiveness * hardness) and chewiness (gumminess * springiness). Ten replicate measurements were made for every treatment.

\section{Statistical Analysis}

All data presented were means of at least two replicates. Analysis of variance was used to test the effect of cooking variables on variation seen in the means, and where there was significant effect, mean separation was carried out using Duncan multiple range test. SAS version 9.2 (SAS 2009) was used for all statistical analyses.

\section{RESULTS AND DISCUSSION}

\section{Physical Characteristics of Bean Analog}

Bean analog show some similarity to navy bean in terms of color after cooking, and shape, though a little rounded on one side than the navy bean (Fig. 2). This was due to knife cut at the point of exiting the extruder. Visual observation did not present any significant difference between bean analog samples except samples with high level of protein $(50 \%$ soy) that show some swelling as compared to others with limited swelling.

TABLE 2. PERCENT PROXIMATE CONTENT OF FLOURS AND FORMULATIONS OF BEAN ANALOG

\begin{tabular}{|c|c|c|c|c|c|c|c|}
\hline Samples & Crude protein & Crude fat & Crude fiber & Ash & Starch & $\mathrm{CHO}$ & $M C$ \\
\hline Sorghum flour & $9.69^{a}$ & $1.49^{9}$ & $0.77^{\mathrm{g}}$ & $3.57 b$ & $72.10^{\mathrm{g}}$ & $75.21^{i}$ & $9.26^{\mathrm{g}}$ \\
\hline Wheat flour & $10.11^{b}$ & $1.05^{c}$ & $0.56^{b}$ & $3.13^{a}$ & $65.30^{f}$ & $74.61^{\mathrm{h}}$ & $10.55^{h}$ \\
\hline Defatted soy flour & $51.60^{h}$ & $0.73^{a}$ & $0.49^{a}$ & $7.96^{f}$ & $1.05^{a}$ & $32.86^{a}$ & $6.36^{\mathrm{a}}$ \\
\hline *NB & 22.99 & 2.32 & 16.08 & 3.91 & 36.47 & 45.6 & 9.13 \\
\hline S35W35Y30 & $23.01^{\mathrm{e}}$ & $1.14^{d}$ & $0.63^{\text {de }}$ & $4.86^{c}$ & $49.69^{d}$ & $63.95^{f}$ & $6.42^{\mathrm{b}}$ \\
\hline S52W17Y30 & $22.43^{c}$ & $1.19^{\mathrm{e}}$ & $0.65^{e}$ & $4.83^{c}$ & $49.80^{d}$ & $62.66^{\mathrm{g}}$ & $8.23^{e}$ \\
\hline S70W0Y30 & $22.65^{d}$ & $1.29^{f}$ & $0.70^{f}$ & $4.97^{c}$ & $51.66^{\mathrm{e}}$ & $63.58^{\mathrm{e}}$ & $6.82^{c}$ \\
\hline S25W25Y50 & $31.12^{\mathrm{g}}$ & $1.01^{\mathrm{b}}$ & $0.58^{b c}$ & $5.72^{\text {de }}$ & $35.29^{b}$ & $54.53^{b}$ & $7.03^{d}$ \\
\hline S37W12Y50 & $30.44^{f}$ & $1.05^{c}$ & $0.60^{\mathrm{cd}}$ & $5.66^{\mathrm{d}}$ & $35.42^{b}$ & $53.50^{d}$ & $8.75^{f}$ \\
\hline S50WOY50 & $30.96^{9}$ & $1.12^{d}$ & $0.64^{\text {de }}$ & $5.93^{e}$ & $36.95^{c}$ & $54.59^{c}$ & $6.86^{c}$ \\
\hline
\end{tabular}

Mean with different superscript in the same column are statistically different $(P<0.05)$.

*Source: Kereliuk and Kozub (1995) and Zucco et al. (2011).

All numbers shown are at least a mean of a duplicate.

$\mathrm{CHO}$, carbohydrate; MC, moisture content; Soy flour, defatted soy flour; NB, navy bean. 
TABLE 3. MOISTURE CONTENT OF BEAN ANALOG-CALCULATED AND MEASURED

\begin{tabular}{lll}
\hline Formulations & $\begin{array}{l}\text { Calculated in-barrel } \\
\text { MC }(\%, w b)\end{array}$ & $\begin{array}{l}\text { Measured MC of } \\
\text { bean analogs, } \\
\text { pre-drying }(\%, w b)\end{array}$ \\
\hline S35W35Y30 & 38.52 & $30.45(0.71)^{\mathrm{a}}$ \\
S52W17Y30 & 35.84 & $30.51(0.41)^{\mathrm{a}}$ \\
S70W0Y30 & 35.34 & $30.38(0.73)^{\mathrm{a}}$ \\
S25W25Y50 & 35.10 & $32.22(0.57)^{\mathrm{b}}$ \\
S37W12Y50 & 35.47 & $31.46(0.68)^{\mathrm{ab}}$ \\
S50W0Y50 & 35.59 & $29.99(0.48)^{\mathrm{a}}$ \\
\hline
\end{tabular}

Mean with different letter in the same column are statistically different $(P<0.05)$; numbers in bracket are standard deviation. $M C$, moisture content; wb, wet basis.

\section{Proximate Content}

Proximate content data for the three main flours used for producing bean analog are shown in Table 2. Moisture in the flours was in the range of $6.36-10.55 \%$ wet weight basis (wb). As expected, soy flour showed higher protein content, and was lower in fat because it was defatted. Sorghum on the other hand showed higher fiber content. Sorghum and wheat flours had more carbohydrates than soy flour. Similar trend was shown in starch content so much more that soy flour showed almost no starch with about $1 \%$ level. Navy bean has a completely different nutrient profile compared to either the three flours used for the formulations or the formulations themselves. Fiber and fat contents were higher in navy bean, while every other component is lower, except protein that was in the range for bean analog formulations with $30 \%$ soy content. Analysis of variance showed that there was significant $(P<0.05)$ effect of flour combination on the difference seen in the proximate content of the different formulation. Protein content of the formulations ranged from 22.43 to $31.12 \%$, while carbohydrate was 53.50 to $63.95 \%$. There is a pattern of change noticeable with these two contents of the formulations, which is traceable to the flour components. As the level of wheat decreased, the protein and carbohydrate initially showed a decrease then increased. Other proximate content namely fat, fiber, ash and starch content increased significantly $(P<0.05)$ as the level of wheat decreased and level of sorghum increased in the formulations.

\section{In-Barrel Moisture Content}

In-barrel moisture content and moisture content (measured) of bean analog pre-drying are presented in Table 3. Measured moisture content ranged from 35.10 to $38.52 \%$ (wb). Almost all the products were produced with the same amount of moisture though slightly different ratio of steam to water was added. Measured moisture content ranged from 29.99 to $32.22 \%$. There was obvious difference between the calculated in-barrel moisture and measured moisture content of the bean analog, post extrusion (pre-drying). This might be due to steam loss in the extruder since the extruder is not a completely closed system. Also, increased level of sorghum $(35,52.5$ and $70 \%)$ tends to decrease the final moisture in the sample after extrusion. Dried samples generally had moisture in the range of $6.42-8.75 \%(\mathrm{wb})$ (Table 2).

\section{Specific Mechanical Energy}

SME of the process varied from 27.41 to $36.54 \mathrm{~kJ} / \mathrm{kg}$. There was some increase in SME noticeable with increased level of sorghum and decreasing amount of wheat in the formulation. This could be due to constituent of sorghum such as starch and fiber which increased concurrently. As starch imbibes water and swells, there is increase in volume and subsequently pressure; this often leads to higher energy requirement in extruder barrel. Higher fiber content has also been reported to increase torque and power consumption during extrusion (Gamon et al. 2013).

\section{Radial Expansion}

The expansion ratio (ER) obtained for the extrudates varied from 1.32 to 1.51. Analysis of variance (ANOVA) showed that there was no significant difference $(P<0.05)$ between means of radial expansion. Generally, all formulation showed minimal expansion ratio, with samples high in starch (30\% soy flour) in terms of either high level of wheat and/sorghum saw minimal expansion in the extrudates, whereas samples high in protein $(50 \%$ soy flour) showed bigger expansion when compared. Adesina et al. (1998); and El-Samahy et al. (2007) all reported a positive correlation between expansion and starch level in extruded products,

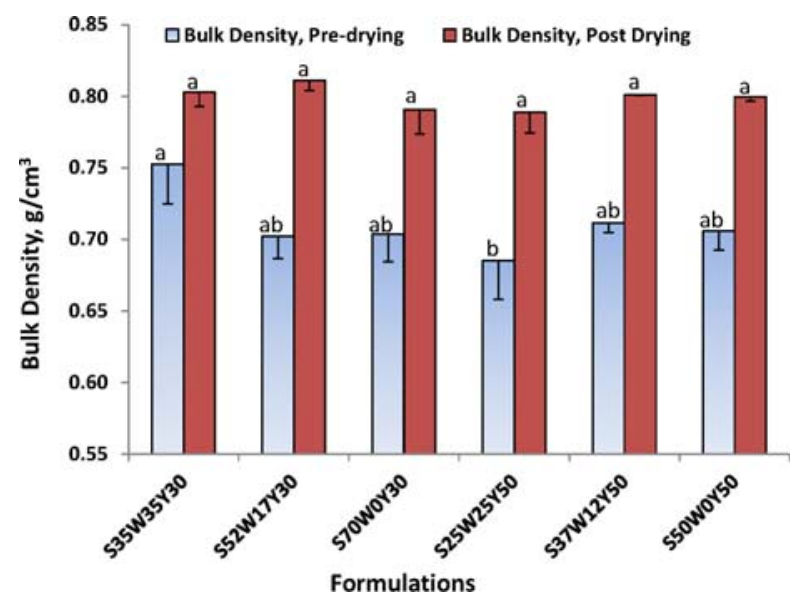

FIG. 3. BULK DENSITY OF EXTRUDED BEAN ANALOG, PRE AND POST DRYING. SAME BAR TYPE WITH DIFFERENT LETTER(S) INDICATE SIGNIFICANT DIFFERENCE AT 5\% PROBABILITY OF ERROR 
TABLE 4. COLOR MEASUREMENTS FOR BEAN ANALOG AND NAVY BEAN

\begin{tabular}{llllll}
\hline Formulation & L* $^{*}$ & $a^{*}$ & & $b^{*}$ & AE \\
\hline S35W35Y30 & $60.90(1.90)^{c}$ & 4.92 & $(0.15)^{\mathrm{c}}$ & $16.26(0.45)^{\mathrm{cd}}$ & $14.35(0.42)^{\mathrm{a}}$ \\
S52W17Y30 & $62.35(1.86)^{\mathrm{c}}$ & 4.54 & $(0.05)^{\mathrm{b}}$ & $15.58(0.47)^{\mathrm{bc}}$ & $12.74(2.01)^{\mathrm{a}}$ \\
S70W0Y30 & $62.32(0.15)^{\mathrm{c}}$ & 4.42 & $(0.11)^{\mathrm{b}}$ & $15.20(0.19)^{\mathrm{b}}$ & $12.65(1.54)^{\mathrm{a}}$ \\
S25W25Y50 & $52.91(0.10)^{\mathrm{a}}$ & 5.68 & $(0.13)^{\mathrm{d}}$ & $16.20(0.12)^{\mathrm{cd}}$ & $22.15(1.71)^{\mathrm{c}}$ \\
S37W12Y50 & $63.22(2.18)^{\mathrm{c}}$ & 6.31 & $(0.23)^{\mathrm{e}}$ & $19.00(0.72)^{\mathrm{e}}$ & $13.69(0.32)^{\mathrm{a}}$ \\
S50W0Y50 & $56.27(0.69)^{\mathrm{b}}$ & 5.49 & $(0.05)^{\mathrm{d}}$ & $16.90(0.24)^{\mathrm{d}}$ & $19.01(1.38)^{\mathrm{b}}$ \\
Navy bean & $74.40(1.74)^{\mathrm{d}}$ & 1.89 & $(0.14)^{\mathrm{a}}$ & $12.49(0.32)^{\mathrm{a}}$ & \\
\hline
\end{tabular}

Column with mean showing different superscript is significantly different at $5 \%$ probability of error.

which is contrary to what is shown in this study. Starch is supposed to lead to expansion when significant gelatinization occur but because of the low thermal and mechanical energy input of the process used in this study, there was minimal expansion from starch swelling. The limited expansion observed in low starch-high protein formulations could be attributed to protein swelling and collapsing due to its viscoelastic property. This was also reflected in the bulk density of the extrudates (Fig. 3). Nyombaire et al. (2011) reported an ER in the range of 1.19-1.36 for extruded red kidney beans (Phaseolus vugaricus L) extruded under similar conditions, and attributed the low ER obtained to the level of protein in their samples. Iwe and Ngoddy (1998) also presented related results for ER of extruded soybean and sweet potato blend. Limited expansion can also be attributed to high in-barrel moisture content and low shear. High water content lowers viscosity of melt in extrusion, impacting starch swelling, creating a dense product with limited expansion (Nyombaire et al. 2011; Perez-Navarrete et al. 2006).

\section{Bulk Density}

Bulk density of the extruded bean analog, before and after drying are shown in Fig. 3. The bulk densities ranged from 0.68 to $0.75 \mathrm{~g} / \mathrm{cm}^{3}$ and 0.79 to $0.81 \mathrm{~g} / \mathrm{cm}^{3}$, for the samples pre and post drying, respectively. Joseph et al. (2013) had reported the average bulk density of navy bean as $1.33 \pm 0.01 \mathrm{~g} / \mathrm{cm}^{3}$, which is significantly higher than those of extruded bean analogs. Bean analog extrudates became significantly denser after drying because the products had lost some moisture. There was significant $(P<0.05)$ difference in the pre-drying bulk density. Bean analogs with equal amount of sorghum and wheat flours, but different levels of soy were significantly different. The difference observed can be attributed to soy protein content, as mechanical energy input was similar for these two samples. There was no significant $(P<0.05)$ effect of formulation on the difference seen in bulk density of dried samples. Bulk density of the dry bean analog is a reflection of low mechanical energy input during extrusion processing.

\section{Color}

Color data are presented in Table 4 . Navy bean showed a significantly $(P<0.05)$ higher whiteness $(74.40 \pm 1.74), L^{*}$ than the extruded bean analog with a range of 56.27-63.22. Bean analogs' less white appearance can be attributed to the
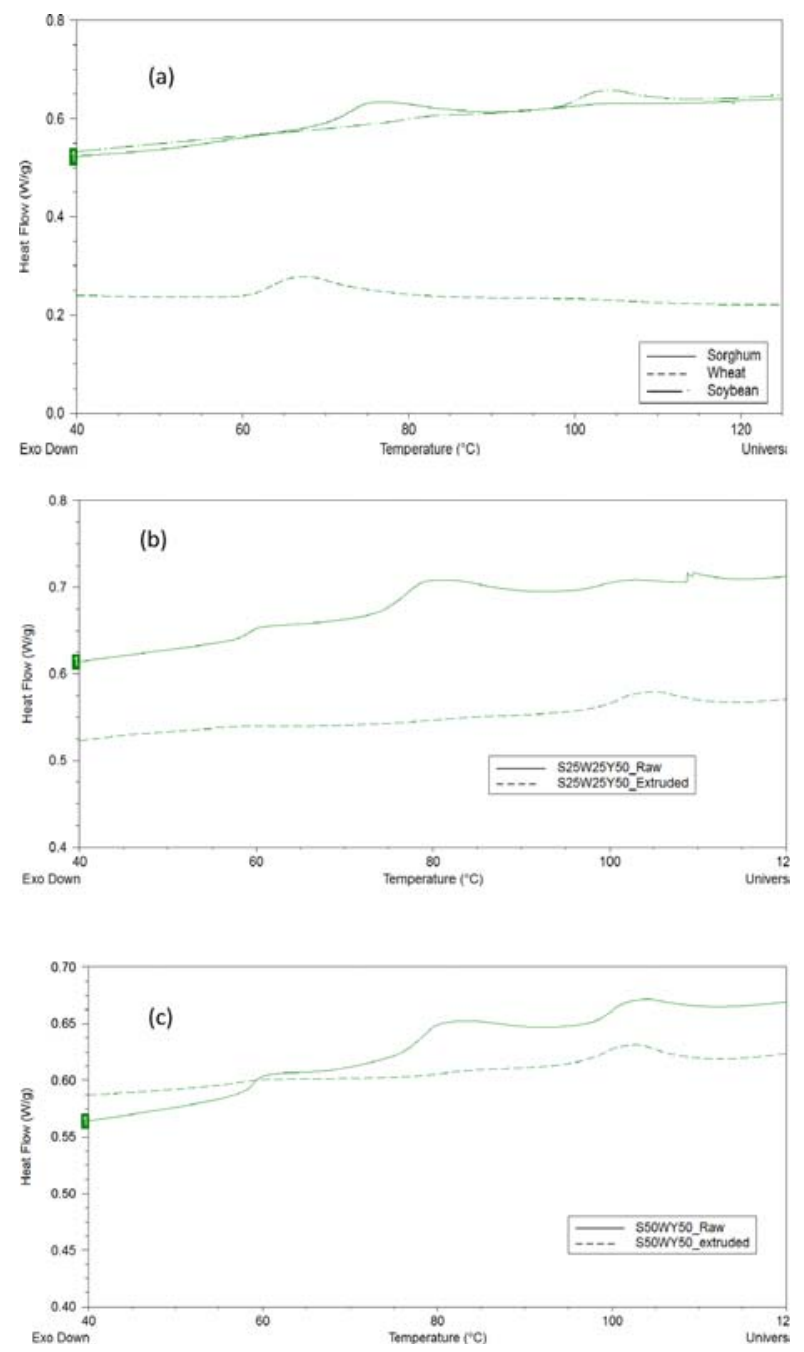

FIG. 4. THERMOGRAMS OF (A) INDIVIDUAL FLOURS AND FLOUR BLENDS AND (B, C) RAW AND EXTRUDED BEAN ANALOG 
TABLE 5. DEGREE OF GELATINIZATION

\begin{tabular}{|c|c|c|c|c|c|c|c|}
\hline \multirow[b]{4}{*}{ Formulation } & \multirow{2}{*}{$\frac{\text { Peak gelatinization }}{\text { Temperature }\left({ }^{\circ} \mathrm{C}\right)}$} & \multirow[b]{2}{*}{ Enthalpy (J/g) } & \multirow{2}{*}{$\frac{\text { Peak gelatinization }}{\text { Temperature }\left({ }^{\circ} \mathrm{C}\right)}$} & \multirow[b]{2}{*}{ Enthalpy (J/g) } & Peak gelatinization & \multirow[b]{2}{*}{ Enthalpy $(\mathrm{J} / \mathrm{g})$} & \multirow[b]{4}{*}{ DG (\%) } \\
\hline & & & & & Temperature $\left({ }^{\circ} \mathrm{C}\right)$ & & \\
\hline & \multicolumn{2}{|c|}{ Flour mix } & \multicolumn{4}{|c|}{ Extruded bean analog } & \\
\hline & \multicolumn{2}{|c|}{ Confounded peaks } & \multicolumn{2}{|c|}{ First peak } & \multicolumn{2}{|c|}{ Second peak } & \\
\hline S35W35Y30 & $69.92(1.49)$ & $3.31(0.30)$ & $52.11(4.57)$ & $1.04(0.10)$ & $78.80(2.18)$ & $0.00(0.00)$ & $54.14(5.98)^{\mathrm{e}}$ \\
\hline S52W17Y30 & $72.27(1.32)^{\star}$ & $3.10(0.08) \dagger$ & $60.31(0.25)$ & $0.77(0.04)$ & - & - & $75.12(2.14)^{c}$ \\
\hline S70W0Y30 & $72.35(0.51)$ & $2.58(0.31)$ & $60.66(0.21)$ & $0.72(0.02)$ & $84.17(0.44)$ & $0.06(0.01)$ & $69.93(3.57)^{d}$ \\
\hline S25W25Y50 & 74.91(1.49) & $2.59(0.08)$ & $62.35(0.54)$ & $0.27(0.00)$ & $84.88(0.75)$ & $0.05(0.01)$ & $87.67(1.13)^{\mathrm{b}}$ \\
\hline S37W12Y50 & $73.08(1.33)$ & $3.15(0.23)$ & $59.97(0.58)$ & $0.13(0.02)$ & $83.62(1.34)$ & $0.05(0.02)$ & $94.33(2.02)^{a}$ \\
\hline S50WY50 & $81.80(1.84)$ & $2.13(0.40)$ & $59.39(0.78)$ & $0.22(0.06)$ & $84.66(0.72)$ & $0.05(0.00)$ & $86.85(3.74)^{b}$ \\
\hline
\end{tabular}

*Only one peak seen.

Mean with different letter in the same column are statistically different $(P<0.05)$.

Numbers in bracket are standard deviation.

DG, degree of gelatinization;

sorghum content. Samples high in sorghum showed darker coloration than the rest. $a^{*}$ and $b^{*}$ color spaces were both significantly $(P<0.05)$ varied due to the formulation. All extruded samples showed a strong yellowness and redness, differing from navy bean. The strong yellowness seen in bean analog samples may be as a result of soybean flour in the formulations. Soy flour has a strong natural yellowness. A big difference is seen in the overall color of extruded bean analog and navy bean, with a difference $(\Delta E)$ ranging from $12.74 \pm 2.01$ to $22.15 \pm 1.71$. The most difference was observed in samples with high soy content.

\section{Degree of Gelatinization}

Thermograms of individual raw flour, raw flour blends and two extruded bean analog are shown in Fig. 4. All the three main flours showed a single enthalpy peak (sorghum: $77^{\circ} \mathrm{C}$ and wheat: $66^{\circ} \mathrm{C}$ ), except for soy flour with two peaks at about 79 and $104^{\circ} \mathrm{C}$. Double peaks have been reported in soy samples, which indicate the denaturation of two polypeptides in soybean namely $\beta$-conglycinin and glycinin (Guerrero et al. 2010; Sobral et al. 2010). Where a protein peak temperature is shown outside of $100^{\circ} \mathrm{C}$ as it is the case in this study, the issue of it being confounded with amyloselipid complex often arises. Amylose-lipid complex peak is usually outside the $100^{\circ} \mathrm{C}$ (Karim et al. 2007). Since starches gelatinize below $100^{\circ} \mathrm{C}$, amylose-lipid complex and second protein peaks did not confound the degree of gelatinization calculation. The degree of gelatinization (DG) for all the bean analog formulations is shown in Table 5 . All the samples except the raw flours and formulation with $52.5 \%$ sorghum exhibited minimum of two peaks. There was a third/ fourth peak shown outside of $100^{\circ} \mathrm{C}$ (Fig. 4 b,c), which could be as a result of amylose-lipid complexes and/or denaturation of glycinin protein in soy flour mentioned earlier. In both raw and extruded samples, wherever peaks are con- founded in one another, the gelatinization enthalpy were integrated as ranging from one end of the first peak to end of the last peak within the $100^{\circ} \mathrm{C}$ boundary. Gelatinization mid-point temperature for the different flour mixtures varied from 69.9 to $81.8^{\circ} \mathrm{C}$ and it tends to increase as the level of sorghum content of the formulation increased. The endothermic heat (enthalpy) of the flours at the point of gelatinization ranged from 2.13 to $3.31 \mathrm{~J} / \mathrm{g}$. Gelatinization midpoint temperature for the first and the second peaks for the extruded bean ranged from 52.1 to $60.7^{\circ} \mathrm{C}$ and 78.8 to
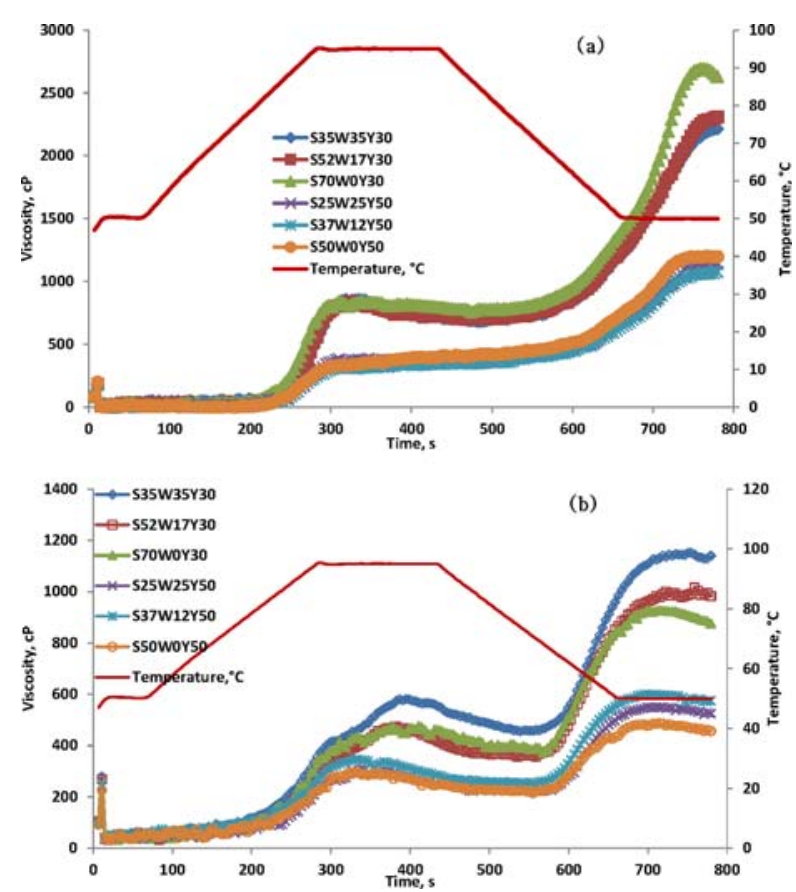

FIG. 5. PASTING PROPERTY CURVES FOR (A) RAW FLOUR BLENDS AND (B) EXTRUDED BEAN ANALOG 
TABLE 6. PASTING PROPERTIES OF RAW FLOUR BLENDS AND EXTRUDED BEAN ANALOG

\begin{tabular}{|c|c|c|c|c|c|c|c|}
\hline & Peak & Trough & Break & Final & Setback & Peak time & Pasting \\
\hline Formulation & \multicolumn{2}{|c|}{ Viscosity Viscosity } & Down & Viscosity & Viscosity & $\min$ & Temp. $\left({ }^{\circ} \mathrm{C}\right)$ \\
\hline \multicolumn{8}{|c|}{ Raw flour blends } \\
\hline S35W35Y30 & $862.0^{c}$ & $678.5^{b}$ & $183.5^{c}$ & $2215.0^{c}$ & $1536.5^{c}$ & $5.42^{\mathrm{a}}$ & $52.05^{a}$ \\
\hline S52W17Y30 & $837.5^{c}$ & $696.0^{b c}$ & $141.5^{c}$ & $2308.0^{d}$ & $1612.0^{d}$ & $5.39^{a}$ & $50.28^{a}$ \\
\hline S70WOY30 & $842.0^{c}$ & $754.0^{c}$ & $88.0^{\mathrm{b}}$ & $2629.5^{e}$ & $1875.5^{\mathrm{e}}$ & $5.45^{\mathrm{a}}$ & $51.43^{\mathrm{a}}$ \\
\hline S25W25Y50 & $395.5^{\mathrm{b}}$ & $360.0^{\mathrm{a}}$ & $35.5^{a}$ & $1141.0^{\mathrm{ab}}$ & $781.0^{\mathrm{ab}}$ & $6.95^{b}$ & $52.35^{a}$ \\
\hline S37W12Y50 & $347.5^{a}$ & $320.0^{a}$ & $27.5^{a}$ & $1075.5^{a}$ & $755.5^{a}$ & $6.69^{b}$ & $87.58^{b}$ \\
\hline S50W0Y50 & $399.5^{\mathrm{b}}$ & $353.5^{\mathrm{a}}$ & $46.0^{\mathrm{ab}}$ & $1195.5^{b}$ & $842.0^{\mathrm{b}}$ & $6.92^{b}$ & $70.73^{\mathrm{ab}}$ \\
\hline \multicolumn{8}{|l|}{ Extrudates } \\
\hline S35W35Y30 & $584.0^{a}$ & $452.0^{\mathrm{a}}$ & $132^{\mathrm{a}}$ & $1138.5^{a}$ & $686.5^{a}$ & $6.52^{b}$ & $77.40^{\mathrm{a}}$ \\
\hline S52W17Y30 & $474.0^{b}$ & $355.0^{\mathrm{b}}$ & $119^{\mathrm{ab}}$ & $982.0^{\mathrm{b}}$ & $627.0^{\mathrm{b}}$ & $6.38^{\mathrm{b}}$ & $72.98^{a}$ \\
\hline S70W0Y30 & $478.0^{\mathrm{b}}$ & $366.5^{b}$ & $112^{\mathrm{ab}}$ & $874.5^{c}$ & $508.0^{c}$ & $6.59^{b}$ & $71.08^{a}$ \\
\hline S25W25Y50 & $307.5^{c}$ & $212.5^{c}$ & $95^{b}$ & $525.0^{d}$ & $312.5^{d}$ & $5.65^{a}$ & $71.85^{a}$ \\
\hline S37W12Y50 & $307.5^{c}$ & $213.5^{c}$ & $94^{\mathrm{b}}$ & $496.0^{\text {de }}$ & $282.5^{\mathrm{e}}$ & $5.75^{a}$ & $51.90^{a}$ \\
\hline S50W0Y50 & $297.0^{c}$ & $214.0^{c}$ & $83^{b}$ & $456.0^{e}$ & $242.0^{f}$ & $5.48^{a}$ & $51.90^{a}$ \\
\hline
\end{tabular}

Mean in the same column section with different superscript are significantly different at $P<0.05$.

All viscosities are in centi-Poise (CP).

Temp, temperature.

$84.9^{\circ} \mathrm{C}$, respectively, while the enthalpy at these points varied from 0.22 to $1.04 \mathrm{~J} / \mathrm{g}$ and 0.001 to $0.06 \mathrm{~J} / \mathrm{g}$, respectively. The DG for the extruded bean ranged from 54.15 to $94.33 \%$. Formulations with lower percentage of soybean showed the least degree of gelatinization. This might be related to the fact that there was more starch per unit volume in these formulations because soy flour contains little or no starch than those with higher level of soy flour. ANOVA showed that there was significant $(P<0.05)$ difference in the degree of gelatinization based on formulation. Trend was such that samples with lower wheat content tend gelatinize better.

\section{Pasting Property}

Rapid visco-analyzer (RVA) response curves showing properties of raw flour blends and ground extruded bean analog flours are presented in Fig. 5a,b, respectively. This characteristic response was common to all bean analog tested. Viscosity increased gradually as the paste was heated under mechanical force, attaining peak viscosity after heating to $95^{\circ} \mathrm{C}$ without any form of cold swell, indicating less starch damage and cooking of bean analog starch during extrusion. The lack of cold swell can also be attributed to amylose-lipid complex, which prevents starch for hydration (Becker et al. 2001). ANOVA showed that there was significant $(P<0.05)$ effect of formulation on the variation observed in the peak viscosity of the raw and extruded bean analogs (Table 6). Peak viscosity for the raw blend varied from 347.5 to 862.0 cP (Table 6). Peak viscosities for the raw blends are significantly $(P<0.05)$ higher than the extruded bean analog. This can be attributed to significant quantity of uncooked starch in raw compared to extruded samples. Ozcan and Jackson (2005) reported the same difference for peak viscosity of raw and extruded corn starch. There is no difference between peak viscosity of raw blends with $30 \%$ soy content. However, with $50 \%$ soy in raw blends, peak viscosity decreased significantly. This is indicative of how ingredients, for example protein, could influence viscosity development during cooking (Batey and Curtin 2000; Ragaee and Abdel-Aal 2006). Núnez et al. (2009) reported that the level of starch and presence of protein in extruded samples have a great effect on the degree of swelling. They also speculated that the degree of swelling could be affected by amylose-lipid complex formation in flour blends. Similar effect of soy level was observed for the extruded bean analog peak viscosity. In extruded samples with 30\% soy level, a significant $(P<0.05)$ decrease was observed in peak viscosity as sorghum content increased and as wheat decreased. This indicated the difference wheat starch has on gelatinization during extrusion.

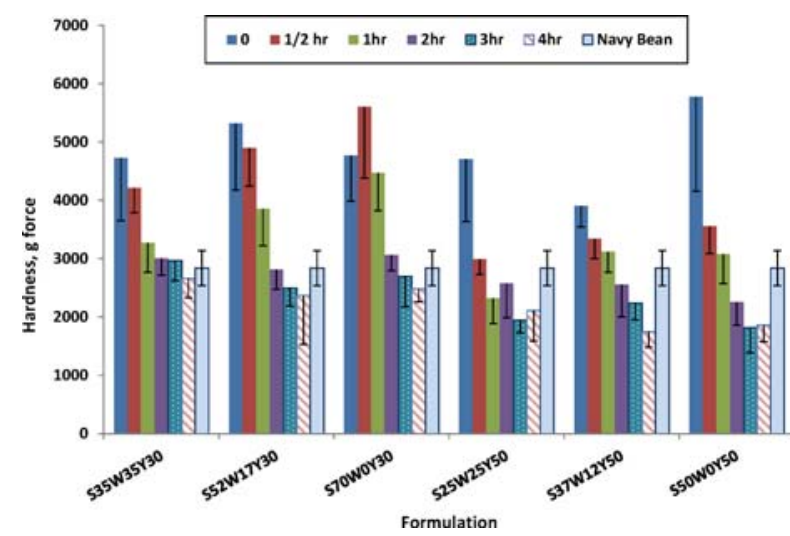

FIG. 6. EFFECT OF SOAKING TIME ON HARDNESS OF COOKED NATURAL (NAVY) AND EXTRUDED BEANS 


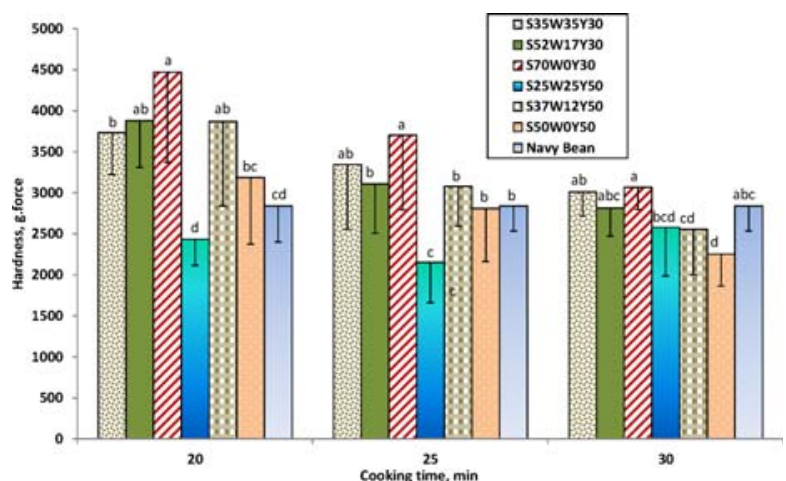

FIG. 7. AVERAGE HARDNESS OF DIFFERENT FORMULATION OF BEAN ANALOG AT DIFFERENT COOKING TIMES

Bars with the same letter under a cooking time is not significantly $(P<0.05)$ different.

This same pattern of high viscosity in low soy samples was also shown for the trough, breakdown, setback and final viscosity (Table 6). Pasting temperatures varied significantly $(P<0.05)$ due to formulation differences, and the range was between $50.28-87^{\circ} \mathrm{C}$ and $51.90-77.40^{\circ} \mathrm{C}$ for raw flour blends and bean analog, respectively. Low soy flour blends attained peak viscosity quicker than high soy blends. This trend reversed in extruded bean analog. The setback viscosity was also observed to be lower in high soy samples, which might be an indication of minimal starch damage linked to lower starch content and protein shielding effect on starch in the samples. Final viscosity, an indication of degree of retrogradation was much higher in raw flour blends and in high starch samples when compared.

\section{Textural Properties and Solid Loss in Bean Analog}

Texture profile analysis (TPA) data from zero soaking time to $4 \mathrm{~h}$, and $30 \mathrm{~min}$ of cooking showed that bean analog subjected to $2 \mathrm{~h}$ of soaking and $30 \mathrm{~min}$ of cooking had the closest hardness to that of cooked navy bean (Fig. 6). Therefore, $2 \mathrm{~h}$ soaking time was selected and then cooking time was varied from 20 to $30 \mathrm{~min}$ to assess the minimum cooking time that would produce hardness similar to cooked navy beans which was taken as the control. Figure 7 shows the average hardness (g-force) of bean analog soaked for $2 \mathrm{~h}$ and then cooked thereafter at different times namely 20, 25 and $30 \mathrm{~min}$. The mean hardness for these cooking times ranged from 2432.49 to $4469.43 \mathrm{~g}$ (force), 2154.35 to $3702.96 \mathrm{~g}$ (force) and 2578.68 to $3065.19 \mathrm{~g}$ (force), respectively. Two way analysis of variance (ANOVA) showed that there was significant $(P<0.05)$ effect of formulation and cooking time on the variation observed in hardness. ANOVA also showed that there was interaction effect of cooking time and formulation on hardness. Generally, hardness decreased with increase in

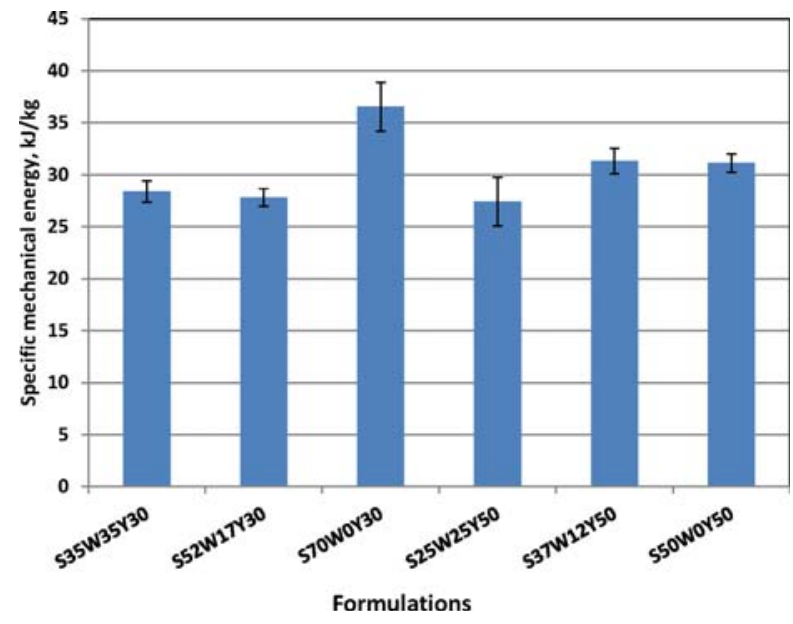

FIG. 8. SPECIFIC MECHANICAL ENERGY DATA FOR EXTRUSION PROCESS

cooking time. Hardness of samples cooked for 30 min was significantly $(P<0.05)$ lower from those cooked at other times. Cooked navy bean hardness was either higher or generally same with bean analog samples cooked for $30 \mathrm{~min}$. Therefore this cooking time is recommended as acceptable to produce bean analog with the desired texture. Low soy formulations tend not to be as hard as those high in sorghum. Increased sorghum content can be associated with high starch and fiber content (Table 2). Sorghum starch effect on hardness tends to be stronger than the effect of wheat protein (gluten), at either 30 or $50 \%$ soy level. This can be a result of both starch and perhaps high fiber content in samples with more sorghum. High starch and fiber has been reported to contribute significantly to hardness due to its thickening effect on air cell wall (Yanniotis et al. 2007; Forsido and Ramaswamy 2011; Wani et al. 2013). This increased hardness can also be related to specific mechanical energy (SME) input. SME of the hard samples were higher than the rest (Fig. 8). High SME is an indication of more energy during extrusion, which could lead to more starch

TABLE 7. SOLIDS LOSSES FOR BEAN ANALOGS AND NAVY BEANS AFTER 2 H SOAKING AND 30 MIN OF COOKING

\begin{tabular}{llll}
\hline Sample & Soaking loss (Vo) & Cooking loss (\%) & TSL (\%) \\
\hline S35W35Y30 & $3.62(0.02)^{\mathrm{c}}$ & $15.57(0.06)^{\mathrm{c}}$ & $19.77^{\mathrm{c}}$ \\
S52W17Y30 & $3.21(0.05)^{\mathrm{b}}$ & $13.81(0.04)^{\mathrm{b}}$ & $17.37^{\mathrm{b}}$ \\
S70W0Y30 & $3.82(0.08)^{\mathrm{d}}$ & $13.46(0.03)^{\mathrm{b}}$ & $17.80^{\mathrm{b}}$ \\
S25W25Y50 & $4.20(0.04)^{\mathrm{e}}$ & $18.67(0.04)^{\mathrm{d}}$ & $23.69^{\mathrm{d}}$ \\
S37W12Y50 & $4.82(0.02)^{\mathrm{f}}$ & $19.30(0.04)^{\mathrm{d}}$ & $25.09^{\mathrm{d}}$ \\
S50W0Y50 & $4.87(0.02)^{\mathrm{f}}$ & $22.76(0.03)^{\mathrm{e}}$ & $28.80^{\mathrm{e}}$ \\
Navy bean & $1.23(0.04)^{\mathrm{a}}$ & $10.78(0.05)^{\mathrm{a}}$ & $12.15^{\mathrm{a}}$ \\
\hline
\end{tabular}

Source: Joseph et al. (2013).

Numbers shown are means of two replicates. Means with different letter are significantly different $(P<0.05 \%)$.

TSL, total solids loss. 
TABLE 8. MEAN VALUES FOR DIFFERENT TEXTURAL PARAMETERS OF BEAN ANALOG AND NAVY BEAN

\begin{tabular}{|c|c|c|c|c|c|c|}
\hline Formulations & CKT & Adhesiveness & Cohesiveness & Springiness & Gumminess & Chewiness \\
\hline S35W35Y30 & \multirow{11}{*}{$20 \mathrm{~min}$} & $-2771^{a b c d}$ & $0.446^{a}$ & 0.5223 & $1666.9^{\mathrm{abc}}$ & $878.07^{a}$ \\
\hline sd & & (10.96) & (0.015) & $(0.101)$ & (235.9) & $(243.50)$ \\
\hline S52W17Y30 & & $-33.36^{\mathrm{cd}}$ & $0.446^{b}$ & 0.4653 & $1733.0^{\mathrm{de}}$ & $804.86^{d c}$ \\
\hline sd & & $(8.28)$ & $(0.013)$ & $(0.042)$ & $(285.14)$ & $(138.46)$ \\
\hline s70W0Y30 & & -15.183 & $0.409^{c}$ & 0.4893 & 1845.03 & $913.61^{a}$ \\
\hline sd & & $(7.46)$ & $(0.021)$ & $(0.101)$ & $(530.0)$ & $(347.42)$ \\
\hline S25W25Y50 & & $-30.30 b^{c d}$ & $0.339^{e}$ & $0.38 I^{\mathrm{cd}}$ & $825.1^{\mathrm{ij}}$ & $311.98^{f}$ \\
\hline sd & & $(12.87)$ & $(0.008)$ & $(0.041)$ & (116.8) & (39.81) \\
\hline S37W12Y50 & & $-20.34^{a b c}$ & $0.343^{\mathrm{ef}}$ & $0.388^{b c}$ & $1337.7^{\mathrm{fg}}$ & $523.91^{\text {ef }}$ \\
\hline sd & & $(12.73)$ & $(0.014)$ & $(0.064)$ & (390.8) & (194.05) \\
\hline S50W0Y50 & & $-20.00^{\mathrm{ab}}$ & $0.308^{\mathrm{gh}}$ & $0.334^{\mathrm{cd}}$ & $998.2^{\text {ghi }}$ & $340.30^{f}$ \\
\hline sd & \multirow{12}{*}{$25 \min$} & $(7.86)$ & $(0.027)$ & $(0.048)$ & (314.5) & $(142.74)$ \\
\hline S35W35Y30 & & $-24.03^{a b c}$ & $0.427^{b}$ & $0.491^{a}$ & $1436.7^{\text {cde }}$ & $712.09^{a b}$ \\
\hline sd & & $(13.72)$ & $(0.015)$ & $(0.087)$ & (371.6) & $(279.60)$ \\
\hline S52W17Y30 & & $-27.33^{d c}$ & $0.427^{a}$ & $0.478^{a b}$ & $1333.2^{\mathrm{ab}}$ & $635.08^{a b}$ \\
\hline $\mathrm{sd}$ & & $(14.61)$ & $(0.017)$ & $(0.029)$ & (297.1) & (137.66) \\
\hline s70W0Y30 & & $-20.18^{a b}$ & $0.408^{c}$ & $0.474^{a}$ & $1519.5^{\mathrm{bcd}}$ & $722.20^{\mathrm{bc}}$ \\
\hline sd & & $(6.75)$ & $(0.019)$ & $(0.052)$ & (432.9) & $(227.24)$ \\
\hline S25W25Y50 & & $-34.99 \mathrm{dc}$ & $0.340^{\mathrm{e}}$ & $0.407^{\mathrm{bc}}$ & 735..$^{i j}$ & $293.22^{f}$ \\
\hline sd & & $(9.94)$ & $(0.022)$ & $(0.052)$ & (197.6) & (52.93) \\
\hline S37W12Y50 & & $-24.34^{\mathrm{ab}}$ & $0.333^{\mathrm{e}}$ & $0.408^{\mathrm{cd}}$ & $1030.0^{\text {de }}$ & $419.85^{\text {de }}$ \\
\hline sd & & $(12.58)$ & $(0.012)$ & $(0.095)$ & (196.1) & $(124.57)$ \\
\hline S50W0Y50 & & $-17.26^{a b}$ & $0.297^{\mathrm{h}}$ & $0.369^{\mathrm{cd}}$ & $844.5^{\text {hij }}$ & $309.80^{f}$ \\
\hline $\mathrm{sd}$ & & $(7.40)$ & (0.019) & $(0.081)$ & $(231.6)$ & $(112.46)$ \\
\hline S35W35Y30 & \multirow{11}{*}{$30 \mathrm{~min}$} & $-26.32^{a b c}$ & $0.426^{b}$ & $0.484^{a}$ & 1283. $I^{\text {def }}$ & $621.21^{\mathrm{cd}}$ \\
\hline $\mathrm{sd}$ & & (17.48) & $(0.020)$ & $(0.035)$ & (136.9) & $(82.87)$ \\
\hline S52W17Y30 & & $-39.70^{d}$ & $0.429^{b}$ & $0.477^{a}$ & $1208.3^{\text {ejg }}$ & $577.73^{\text {cde }}$ \\
\hline sd & & $(20.06)$ & $(0.023)$ & $(0.046)$ & $(177.8)$ & $(113.35)$ \\
\hline S70W0Y30 & & $-30.08^{b c d}$ & $0.389^{c}$ & $0.474^{a}$ & $1192.0^{\text {ejg }}$ & $563.02^{\text {cde }}$ \\
\hline sd & & $(14.66)$ & $(0.021)$ & $(0.074)$ & $(110.0)$ & $(90.06)$ \\
\hline S25W25Y50 & & $-26.04^{\mathrm{abc}}$ & $0.330^{\mathrm{ef}}$ & $0.385^{\mathrm{cd}}$ & $856.8^{\text {hij }}$ & $334.41^{f}$ \\
\hline sd & & $(9.35)$ & $(0.016)$ & $(0.048)$ & $(222.8)$ & (107.68) \\
\hline S37W12Y50 & & $-26.48^{a b c}$ & $0.318^{f g}$ & $0.358^{\mathrm{cd}}$ & $818.4^{\text {hij }}$ & $287.09^{f}$ \\
\hline sd & & (15.63) & $(0.017)$ & $(0.065)$ & (211.8) & $(63.37)$ \\
\hline S50W0Y50 & & $-19.20^{a b}$ & 0.292 & $0.397^{\mathrm{cd}}$ & $659.6^{j}$ & $258.19^{f}$ \\
\hline sd & \multirow{3}{*}{$30 \mathrm{~min}$} & $(7.80)$ & $(0.007)$ & $(0.056)$ & $(115.4)$ & $(40.34)$ \\
\hline NB & & $-6.00 *$ & $0.150 *$ & 0.5203 & $420.8^{k}(112.1)$ & $214.20^{g}$ \\
\hline SD & & $(2.80)$ & $(0.03)$ & $(0.200)$ & & $(82.0)$ \\
\hline
\end{tabular}

Different letter superscript in the same column indicate significant difference at $r<\mathrm{U}$.Ud.

* Significantly different $(l j<U . U d)$ from others.

$\mathrm{NB}$, navy bean; LKI, cooking time in minute; sd, standard deviation, number in parenthesis.

gelation, better binding and hence a harder product. Ma et al. (2012) reported strong correlation between hardness and screw speed (function of SME) of extruded breadfruit. Wu et al. (2007), however, reported decreasing hardness for extruded flaxseed and corn meal mixture. They have used a much higher screw speed (200-400 rpm), and this led to more expanded product. Textural properties of heterogeneous samples are complicated, and based on extent of different chemical and physical changes during processing. Examples of such chemical changes include the extent of starch gelatinization, starch polymer degradation or depolymerization. The extent of these changes could have opposing effect on textural properties. In bean analog, SME was not high enough to produce starch swelling leading to porous material, which leads to less hardness. The degree of energy input in bean analog production is just sufficient enough to produce partial starch gelatinization creating hard matrix instead. Hardness difference based on soy effect was also reported by Falade et al. (2003) on cowpea-based snack food that has been substituted with various levels of soy flour and deep-fat fried. They showed that samples high in soy were less hard than the rest. They attributed this change to increase in soy protein content of the product, which has less binding property. 
Total solid loss (TSL) obtained after $2 \mathrm{~h}$ of soaking and 30 min of cooking for navy bean and bean analog are shown in Table 7. Significant loss was seen during cooking than soaking. Bean analog TSL varied from 17.37 to $28.80 \%$, while navy bean had a significantly $(P<0.05)$ lower total solid loss at $12.5 \%$ compared to bean analog. ANOVA showed that there was significant $(P<0.05)$ effect of formulation on losses observed in cooked bean analog. Also, there was significantly less solid leaching in bean analog samples that had high wheat and low soy flour content. This could be attributed to both protein (gluten) and starch content of wheat acting as a binder to keep the grains intact during the soaking and cooking process (Joseph et al. 2013). Samples with high leaching level also had grains with lots of cracked surface and disintegrated pieces, a further indication of poor binding. Generally, solid loss is quite high in the extruded bean analog, and there is therefore a need to improve this characteristic of the product by use of binders.

Table 8 presents other TPA data for the soaked and cooked bean analog, and navy beans. Generally, ingredients and cooking duration had significant $(P<0.05)$ influence on the variations that were observed in most of the textural properties. Adhesiveness, which is also referred to as stickiness is a measure of force required to pull a material off a surface. ANOVA showed that the effect of cooking time and ingredient were significant $(P<0.05)$ on the variation observed in adhesiveness. Bean analog adhesiveness showed a pattern of slight decrease as the sorghum content increased and wheat flour level reduced, then an increase again when wheat is taken away completely from the formulation. This trend is similar to that shown by crude protein in Table 2, among other proximate content. Sample with higher soy content were found to be more adhesive than others. The effect of high protein is also shown here with regards to physicochemical changes in soy protein during cooking, which makes the product stickier. Yoo et al. (2013) reported a higher stickiness (adhesiveness) in extruded rice made from combination of sorghum and wheat flours compared to others from corn and wheat flours, and rice flour, attributing this to amylose molecules leaching from the starch granules on hydration. Navy bean was the least adhesive. Table 8 also shows that there was significant $(P<0.05)$ effect of cooking time on cohesiveness of bean analog. However cohesiveness reduced with decrease in starch content of the formulations. Samples having more wheat flour showed higher cohesiveness. Also, formulations with low soy content showed higher cohesiveness. Navy bean showed the least cohesiveness. ANOVA showed that there was no significant effect of cooking time $(P<0.05)$ on the variation observed in springiness at the two levels of soy used. However, significant differences were seen between 30 and 50\% soy samples across cooking times. Higher soy level produced higher springiness for all cooking time. Springiness was also affected by formulation differences. Gumminess is a product of hardness and cohesiveness. Therefore the harder and more cohesive a product is, the gummier it is. This pattern was evident in the formulations, when samples with 30 and 50\% soy level were compared collectively. Formulations cooked for longer time were less gummy, indicating a possibility of starch degradation. Also, a consistent pattern of decrease was observed for gumminess at 30 min cooking time as a result of increase in sorghum content. Chewiness, which is dependent on gumminess and springiness, was significantly influenced by the by the quantity of different flours in the formulation and cooking time. Longer cooking time and increased level of soy produced products there were more chewy (less chewing force). For all textural characteristics, navy beans had a completely different characteristics, it was less adhesive, less cohesive, comparable springiness with bean analog, but less gummy and chewy than bean analog.

\section{CONCLUSION}

Bean analog was produced using cold extrusion process with low mechanical energy input leading to partially cooked, minimally expanded and dense products. The degree of gelatinization was a function of soy content. And the pasting properties showed minimal starch damage during extrusion for all formulations. Wheat flour was an essential ingredient that led to good binding and some reduction in cooking loss during soaking and cooking. The soybean and sorghum in the formulations improved functionality and bolster nutrient profile but caused higher soaking and cooking loss. Soaking for 2 hours and cooking for $30 \mathrm{~min}$ gave texture (hardness) similar to navy bean. Textural properties were significantly influenced by how long the samples were soaked, cooked and the starch-protein composition of the products. Increase in cooking time and soy four level reduced the hardness of the products. TPA of bean analog showed variation based on products' constituent and cooking conditions, and they were all different from navy bean.

\section{ACKNOWLEDGMENTS}

The authors would like to thank Kansas Grain Sorghum Commission and the International Science Education (ISE) program of the United States Department of Agriculture for funding support. We also thank operations staff in the Kansas State University Extrusion Lab, Eric Maichel and Trevor Huppert, for their assistance in pilot-scale extrusion experiments.

\section{REFERENCES}

ABU-GHOUSH, M., ALAVI, S., ADHIKARI, K., AL-HOLY, M. and AL-DABBAS, M. 2015. Sensory and nutritional properties 
of a novel cooked extruded lentils analog. J. Food Process. Preserv. 39, 1965-1975. DOI: 10.1111/jfpp.12436.

ADEDEJI, A.A., SUHR, E., BHADRIRAJU, S. and ALAVI, S. 2016. Drying characteristics of bean analog - A sorghum based extruded product. J. Food Process. Preserv. DOI:10.1111/ jfpp. 12856.

ADESINA, A.A., SOWBHAGTA, C.M., BHATTACHARYA, S. and ZAKIUDDIN, A.S. 1998. Maize-soy-based ready-to-eat extruded snack food. J. Food Sci. Technol. 35, 40-43.

ALAVI, S., BUGUSU, B., CRAMER, G., OMAR, D., LEE, T.-C., MCENTIRE, J. and WAILES, E. 2008. Rice fortification in developing countries: A critical review of the technical and economic feasibility, http://www.a2zproject.org//Food-Rice-FortificationReport-with-Annexes-FINAL.pdf. (accessed July 6, 2012).

ALONSO, R., AGUIRRE, A. and MARZO, F. 2000. Effects of extrusion and traditional processing methods on antinutrients and in vitro digestibility of protein and starch in faba and kidney beans. Food Chem. 68, 159-165.

AOAC. 2010. Method 920.39: Crude fat in feeds, cereal grains and forages, method 930.15: Moisture determination, method 942.05: Ash in feed and food, method 990.03: Crude protein combustion method, method 996.11: Total starch assay procedure. In Anonymous Official Methods of Analysis of AOAC International, 18th Ed., AOAC International, Gaithersburg, MD.

AOCS. 2009. Approved procedure Ba 6a-05: Crude fiber analysis in feeds by filter bag technique. In Official Methods and Recommended Practices, 6th Ed., American Oil Chemists' Society, Champaign, IL.

BATEY, I.L. and CURTIN, B.M. 2000. The effects on the pasting viscosity of starch and flour of different operating conditions for the Rapid Visco Analyzer. Cereal Chem. 77, 754-760.

BAUDOIN, J.P. and MAQUET, A. 1999. A case study in Phaseolus. Biotechnology Agronomy Sociology Environment 3, 220-224.

BECKER, A., HILL, S.E. and MITCHELL, J.R. 2001. Relevance of amylose-lipid complexes to the behaviour of thermally processed starches. Starch/Stärke 53, 121-130.

BOATENG, J., VERGHESE, M., WALKER, L and OGUTU, S. 2008. Effect of processing on antioxidant contents in selected dry beans (Phaseolus spp. L.). LWT - Food Sci. Technol. 41, 1541-1547.

CROSBIE, G.B. and ROSS, A.S. (eds.) 2007. The RVA Handbook. American Association of Cereal Chemists International (AACCI) Press, St. Paul, MN.

DE MESA-STONESTREET, N.J., ALAVI, S. and BEAN, S.R. 2010. Sorghum proteins: The concentration, isolation, modification, and food applications of kafirins. J. Food Sci. 75, R90-R104.

DE MESA-STONESTREET, N.J., ALAVI, S. and GWIRTZ, J. 2012. Extrusion-enzyme liquefaction as a method for producing sorghum protein concentrates. J. Food Eng. 108, 365-375.

EL-SAMAHY, S.K., ABD EL-HADY, E.A., HABIBA, R.A. and MOUSSA-AYOUB, T.E. 2007. Some functional, chemical, and sensory characteristics of cactus pear rice-based extrudates. J. Prof. Assoc. Cactus Dev. 9, 136-147.

FALADE, K.O., ADEDEJI, A.A. and AKINGBALA, J.O. 2003. Effect of soybean substitution for cowpea on physical, composi- tional, sensory and sorption properties of akara Ogbomoso. Eur. Food Res. Technol. 217, 492-497.

FAPOJUWO, O.O., MAGA, J.A. and JANSEN, G.R. 1987. Effect of extrusion cooking on in vitro protein digestibility of sorghum. J. Food Sci. 52, 218-219.

FORSIDO, S.F. and RAMASWAMY, H.S. 2011. Protein rich extruded products from tef, corn and soy protein isolate blends. Ethiopian J. Appl. Sci. Technol. 2, 75-90.

GAMON, G., EVON, P. and RIGAL, L. 2013. Twin-screw extrusion impact on natural fibre morphology and material properties in poly (lactic acid based biocomposites. Ind. Crops Prod. 46, 173-185.

GONZALEZ, R., TORRES, R. and DEGREEF, D. 2002. Extrusioncoccion de cereales. Boletin 36, 104-115, SBCTA, Campinas.

GUERRERO, P., RETEGI, A., GABILONDO, N. and DE LA CABA, K. 2010. Mechanical and thermal properties of soy protein films processed by casting and compression. J. Food Eng. 100, 145-151.

IWE, M.O. and NGODDY, P.O. 1998. Proximate composition and some functional properties of extrusion cooked soybean and sweet potato blends. Plant Foods Human Nutr. 53, 121-132.

JOSEPH, M., ADEDEJI, A.A. and ALAVI, S. 2013. Novel delivery mechanism for nutrition using sorghum based extruded precooked "beans." Institute of Food Technology (IFT), Food Engineering Division Poster Session. Held at Chicago, IL USA July 13-16, 2013. Poster No. 031-15.

KARIM, A.A., CHANG, Y.P., FAZILAH, A. and ZAIDUL, I.S.M. 2007. Exothermic transitions on cooling of gelatinized native rice starch studied by differential scanning calorimetry. J. Phys. Sci. 18, 37-47.

KHATTAB, R.Y. and ARNTFIELD, S.D. 2009. Nutritional quality of legume seeds as affected by some physical treatments. LWT Food Sci. Technol. 42, 1113-1118.

KODAVALI, S.S., ADHIKARI, K. and ALAVI, S. 2012. Effects of soy protein isolate, calcium carbonate, and pre-gelatinized wheat starch on oil uptake and texture of soy based snacks. A paper presented at AACCI International Annual Conference held at Hollywood Florida. September 30-October 3, 2012. Paper No. 156-P.

KERELIUK, G.R. and KOZUB, G.C. 1995. Chemical composition of small white (navy) beans. LWT - Food Sci. Technol. 28, 272-278.

MA, H., PAN, Z., LI, B., ATUNGULU, G.G., OLSON, D.A., WALL, M.M. and MCHUGH, T.H. 2012. Properties of extruded expandable breadfruit products. LWT - Food Sci. Technol. 46, 326-334.

NÚÑEZ, M., SANDOVAL, A.J., MÜLLER, A.J., DELLA VALLE, G. and LOURDIN, D. 2009. Thermal characterization and phase behavior of a ready-to-eat breakfast cereal formulation and its starchy components. Food Biophys. 4, 291-303.

NYOMBAIRE, G., SIDDIQ, M. and DOLAN, K.D. 2011. Physicochemical and sensory quality of extruded light red kidney bean (Phaseolus vulgaris L.) porridge. LWT - Food Sci. Technol. 44, 1597-1602.

OZCAN, S. and JACKSON, D.S. 2005. Functionality behavior of raw and extruded corn starch mixtures. Cereal Chem. 82, 223-227. 
PEREZ-NAVARRETE, C., GONZALEZ, R., CHEL-GUERRERO, L. and BETANCUR-ANCONA, D. 2006. Effect of extrusion on nutritional quality of maize and Lima bean flour blends. J. Sci. Food Agric. 86, 2477-2484.

QUEIROZ, K.S., OLIVIERA, A.C., HELBERG, E., REIS, S.M. and CARRARO, F. 2002. Soaking the common beans in a domestic preparation reduced the contents of Raffinose-toye oligosaccharides but did not interfere with nutritive value. J. Nutr. Sci. Vita 48, 283-289.

RAGAEE, S. and ABDEL-AAL, E.M. 2006. Pasting properties of starch and protein in selected cereals and quality of their food products. Food Chem. 95, 9-18.

ROONEY, L.W. 2003. Overview: Sorghum and millet food research failures and successes. Food science faculty, cereal quality laboratory, soil and crop science department. Texas A \&M University USA. p. 4. http://www.afripro.org.uk/papers/ Paper09Rooney.pdf (accessed May 27, 2013).

SAS. 2009. SAS User's Guide: Statistics (Version 9.2). SAS Institute Inc., Cary, NC.

SOBRAL, P.A., PALAZOLO, G.G. and WAGNER, J.R. 2010. Thermal behavior of soy protein fractions depending on their preparation methods, individual interactions, and storage conditions. J. Agric. Food Chem. 58, 10092-10100.

TOSH, S.M. and YADA, S. 2010. Dietary fibers in pulse seeds and fractions: Characterization, functional attributes, and applications. Food Res. Int. 43, 450-460.

USAID. 2011. United State Agency for International Development. U.S. International Food Assistance Report 2011, http://
www.usaid.gov/sites/default/files/documents/1866/F. Y. \%, 202011\%20IFAR\%20FINAL.pdf (accessed May 17, 2013).

USDA. 2010. United State Department of Agriculture. Grain: World Markets and Trade - No Global Shortage of Food Grains. http://www.fas.usda.gov/grain/circular/2010/08-10/grainfull0810.pdf (accessed April 24, 2012).

WANI, I.A., SOGI, D.S., WANI, A.A. and GILL, B.S. 2013. Physico-chemical and functional properties of flours from Indian kidney bean (Phaseolus vulgaris L.) cultivars. LWT - Food Sci. Technol. 53, 278-284.

WU, W., HUFF, H.E. and HSIEH, F. 2007. Processing and properties of extruded flaxseed corn puff. J. Food Process. Preserv. 31, 211-226.

YANNIOTIS, S., PETRAKI, A. and SOUMPASI, E. 2007. Effect of pectin and wheat fibers on quality attributes of extruded cornstarch. J. Food Eng. 80, 594-599.

YASMIN, A., ZEB, A., KHALIL, A.W., PARACHA, G.M. and KHATTAK, A.B. 2008. Effect of processing on anti-nutritional factors of red kidney bean (Phaseolus vulgaris) grains. Food Bioprocess. Technol. 1, 415-419.

YOO, J., ALAVI, A., ADHIKARI, K., HAUBB, M.D., ABERLE, R.A. and HUBER, G. 2013. Rice-shaped extruded kernels: Physical, sensory and nutritional properties. Int. J. Food Prop. 16, 301-321.

ZUCCO, F., BORSUK, Y. and ARNTFIELD, S.D. 2011. Physical and nutritional evaluation of wheat cookies supplemented with pulse flours of different particle sizes. LWT - Food Sci. Technol. 44, 2070-2076. 